\title{
A Macroscopic Analysis of Human Dentition at Late Chalcolithic Çamlıbel Tarlası, North Central Anatolia, with Special Reference to Dietary and Non-masticatory Habits
}

\author{
Benjamin Irvine ${ }^{\mathrm{a}^{*}}$, Jayne-Leigh Thomas ${ }^{\mathrm{b}}$, Ulf Dietrich-Schoop ${ }^{\mathrm{c}}$ \\ ${ }^{a}$ Institut für Vorderasiatische Archäologie, Freie Universität Berlin, Hüttenweg 7, 14195 Berlin, Germany \\ ${ }^{b}$ Office of the Native American Graves Protection and Repatriation Act, Indiana University, Student Building 318,701 E. Kirkwood Ave, Bloomington, \\ Indiana USA 47403 \\ 'School of History, Classics and Archaeology, University of Edinburgh, William Robertson Wing, Old Medical School, Teviot Place, Edinburgh, EH8 9AG, UK
}

\section{ARTICLE INFO}

\section{Article history:}

Received: 20 February 2014

Accepted: 11 July 2014

\section{Key words:}

Late Chalcolithic

Turkey

dental pathology

abrasion

diet

non-masticatory use

\begin{abstract}
Çamlıbel Tarlası (3590-3470 cal BC) is a small farming settlement with metallurgical activity in north central Anatolia. Studies have demonstrated a direct relationship between diet, subsistence patterns, occupational habits and macrowear patterns and dental pathologies. In total 282 teeth from 26 individuals were macroscopically examined. The results showed that in many ways the inhabitants were typical of a Late Chalcolithic population with a subsistence based on mixed agriculture. Dental wear and pathologies were documented including abrasion, attrition, chipping, "cupping", grooves, caries, calculus and enamel hypoplasias. There was also an interesting age-differentiated wear pattern, and purple/red discoloured teeth. These dental pathologies and lesions are hypothesised to have been the result of dietary and food processing habits such as the consumption of carbohydrates and the use of grinding stones. Habitual extra masticatory use during the manufacturing of lithics, metal, and fibre processing is also thought to have resulted in the observed dental lesions.
\end{abstract}

\section{Introduction}

"Teeth are one of the most enduring physical evidences of the existence of an individual after death" (Albashaireh, Al-Shorman 2010, 205). Macro and microscopic analysis of dental material can provide us with information not only about an individual and their dietary, subsistence and habitual habits, but the nutritional and health status of past populations (Palubeckaite et al. 2006, 355). Dental wear and pathology, and changes in rates and prevalence, can record important stages in human evolution and development; the types of dietary resources utilised, nutritional adequacy, oral hygiene, cultural modifications, non-dietary uses of the dentition, the development of fire and cooking, food processing techniques and the adoption and utilisation of grinding tools, the adoption and intensification of agriculture and the invention and use of pottery (Bonfiglioli et al. 2004,

*Corresponding author. E-mail: b.irvine@hotmail.co.uk
448; Erdal 2008, 152; Eshed et al. 2006, 146, 152; Watson et al. 2011; Scott, Winn 2010, 724; Smith 1984, 39; Hillson 2000, 273; Lieverse et al. 2007, 323).

The main aspects investigated are dental pathology and dental wear. Teeth are subject to collective damage from a diverse set of factors such as contact and wear with other teeth, food consistency, grit in the diet and acid erosion (Kieser et al. 2001, 206). Different wear patterns are produced by variations in diet and daily task activities (Deter 2009, 247; Hillson 1996, 292). Numerous studies have focused on the fact that the prevalence and distribution of dental pathologies can give us clues as to diet, nutrition and subsistence (Lukacs 1989, 261; Mays 1998, 146).

The analysis of dental defects from non-masticatory use allows us to reconstruct elements of past subsistence, types of production activities, the division of labour, hygiene practises, habitual behaviour and individual lifestyles or habits (Lorkiewicz 2011, 538; Molnar 2008, 423). Nondietary wear on the dentition can be caused by using the teeth as a tool, grinding or clenching the teeth together (bruxism), 


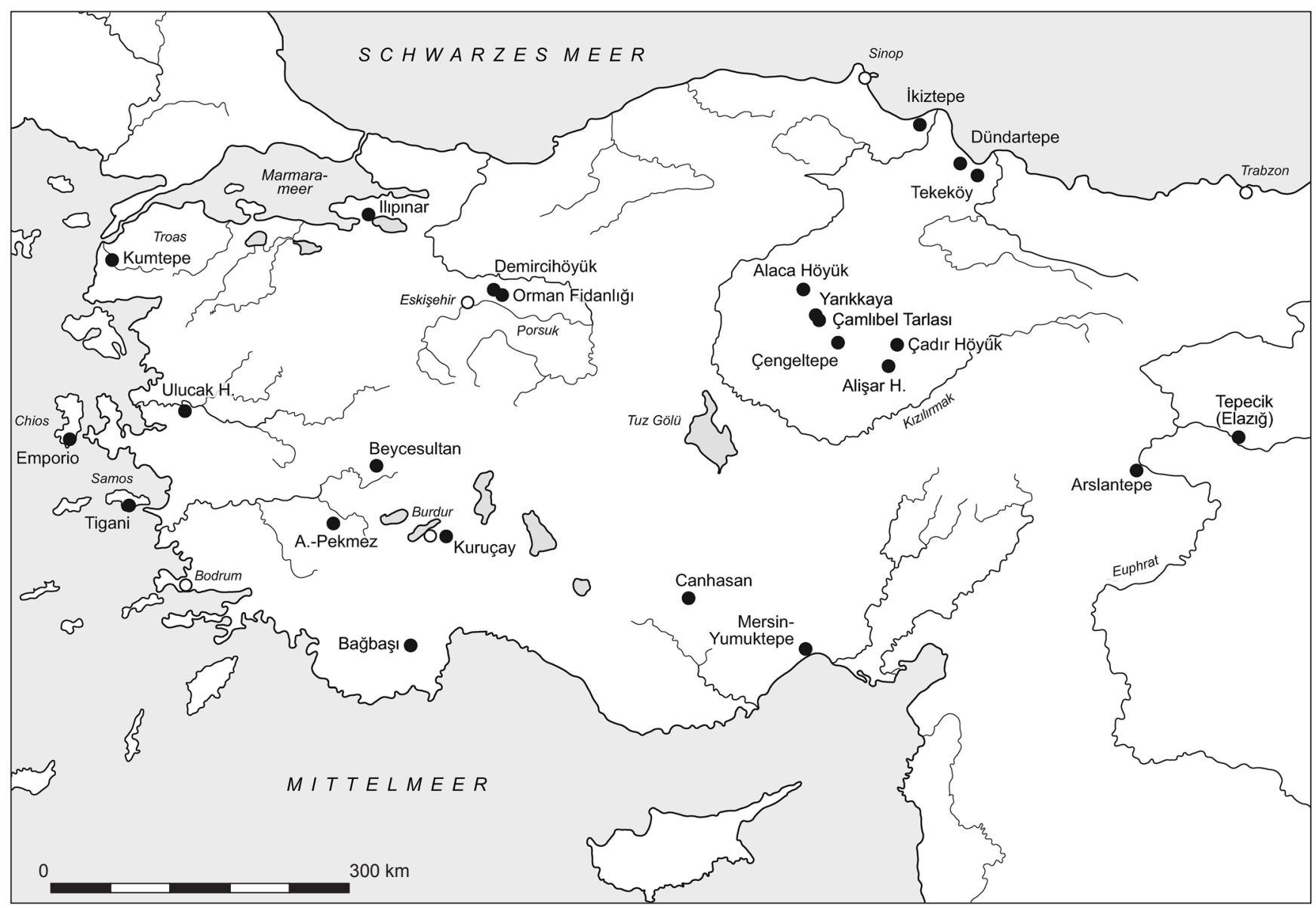

Figure 1. Map showing location of Çamlıbel Tarlası in context of Late Chalcolithic Anatolia (Çamlıbel Tarlası Excavation Archive).

holding objects between the teeth and objects rubbing against the surface of the tooth (e.g. a lip ring) (Deter 2009, 247; Hillson 2000, 273). Studies have also aimed at examining the use of the dentition in extra-masticatory contexts as the frequency of traumatised teeth, the patterning of damage among different teeth, and the age, sex and status position of individuals with damaged teeth can provide a vast wealth of information on past human populations and their behaviour (Milner, Larsen 1991, 367).

Work on this topic has developed over the last decade and has done so due to the increase in interest, and an increased understanding and realisation of the importance of dental wear and pathology for inferring past diets and lifestyles. It has also been the consequence of advancement and increased availability of technology. The application of the radiograph and SEM, and now the development of 3-D scanning technology, have vastly improved the resources available to the researcher for conducting thorough, accurate and reliable studies of dentition.

This research focuses on the examination and analysis of dental pathologies and wear in the skeletal population of Çamlıbel Tarlası located in central Anatolia. Teeth from both grave and secondary contexts were assessed in order to evaluate the wear patterns and their potential relationship with diet or non-masticatory habitual use. Data accumulated will be discussed in comparison with the wider context of the social and economic characteristics of the site and on the Chalcolithic Period in this area.

\section{The Site}

The site of Çamlıbel Tarlası (Figures 1 and 2) is located near the modern town of Boğazkale on the north central Anatolian plateau approximately $1000 \mathrm{~m}$ above sea level. The excavation of this site (over three seasons, 2007-2009) was initiated as a sub-project of the Boğazköy Expedition run by the DAI (Deutsches Archäologisches Institut), in order to understand the prehistoric periods of the area preceding the rise of the Hittite kingdom; who founded their capital Hattusha $2.5 \mathrm{~km}$ east of Çamlıbel Tarlası at Boğazköy (Schoop 2008, 150; 2011, 54). Moreover, the project aimed at exploring the social and economic characteristics of a hamlet site apparently highly typical for the north central Anatolian area (Schoop 2011, 54). Early sites around Boğazköy are small flat settlements in elevated positions along the slope of the Budaközü Plain (Schoop 2011, 55).

\subsection{Burials}

Excavation has revealed four main phases of human activity interrupted by shorter periods of ephemeral and probably 
Figure 2. View of Çamlıbel Tarlası, looking from West to East (Çamlıbel Tarlası Excavation Archive).

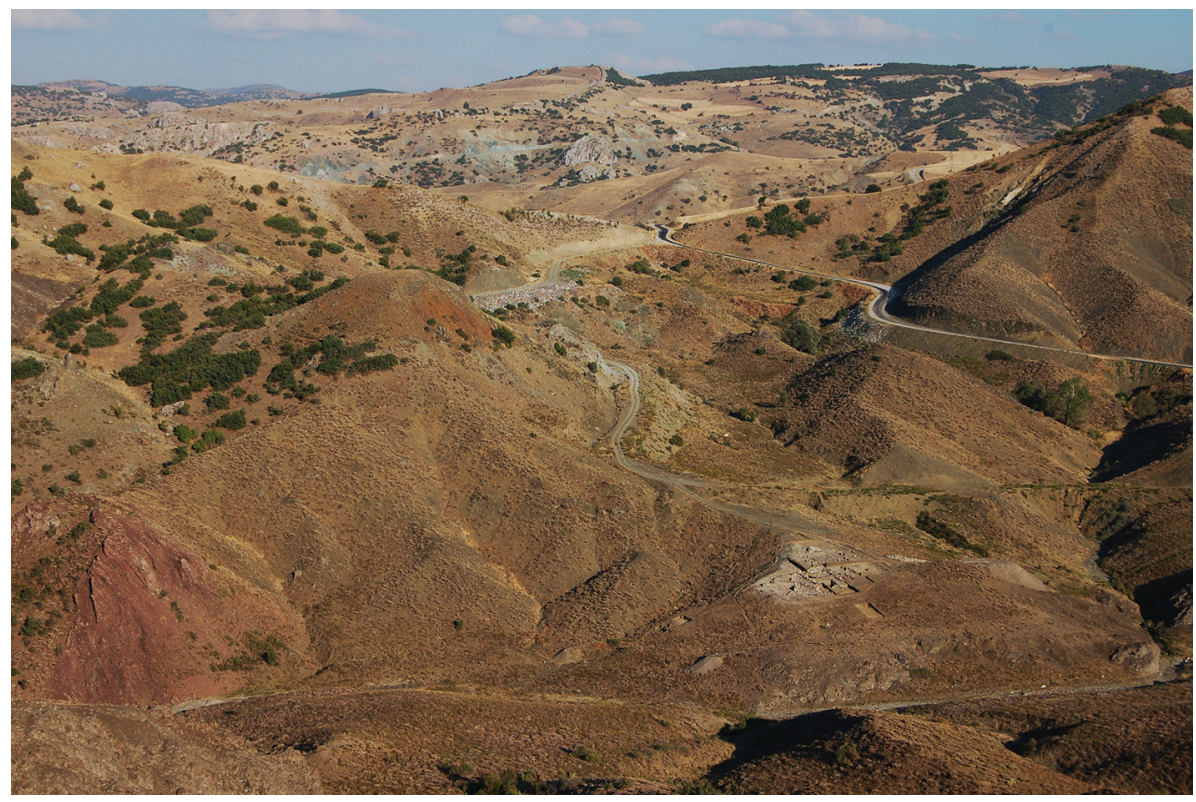

seasonal use (Schoop 2010a, 199; 2011, 55). All phases have been radio carbon dated to the Late Chalcolithic Period; early to middle $4^{\text {th }}$ millennium $\mathrm{BC}$ with a site use-span

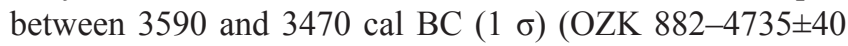
bp, OZK 883-4790 \pm 30 bp, OZK 886-4725 \pm 35 bp, OZK $887-4780 \pm 30$ bp : CALIB 5.0 by M. Stuiver, P. J. Reimer, and R. W. Reimer 2005 (online: <http://calib.qub.ac.uk/ calib/>) (Schoop et al. 2009, 66-67). In total, 19 individuals were recovered from a mixture of jar and primary inhumation burials, with another nine individuals recovered from secondary contexts (Thomas 2011, 73). The people of Çamlıbel Tarlası practised age-differential burial as babies and very young children were buried in jars as possible secondary burials, underneath house floors, or placed adjacent to the house walls (Schoop 2009, 56; 2010a, 195). This is a phenomenon seen across other parts of the Near East in the (Late) Chalcolithic and into the Early Bronze Age; for example infant jar burials beneath the houses of floors are seen during this period (ca. 5000-2500 BC) in the southern Levant, and central and south eastern Anatolia (Steadman et al. 2008, 74; Stein et al. 1996, 210; Ullinger 2010, 33). Older children and adults were inhumed in primary burials in the Hocker position (Figure 3) with their heads to the South and facing East (Schoop 2010a, 192).

\subsection{Economy}

The faunal, floral and material culture findings from Çamlıbel Tarlası all point to small scale agriculture being the primary

Figure 3. Juvenile skeleton from Grave 14 (Çamlıbel Tarlası Excavation Archive).

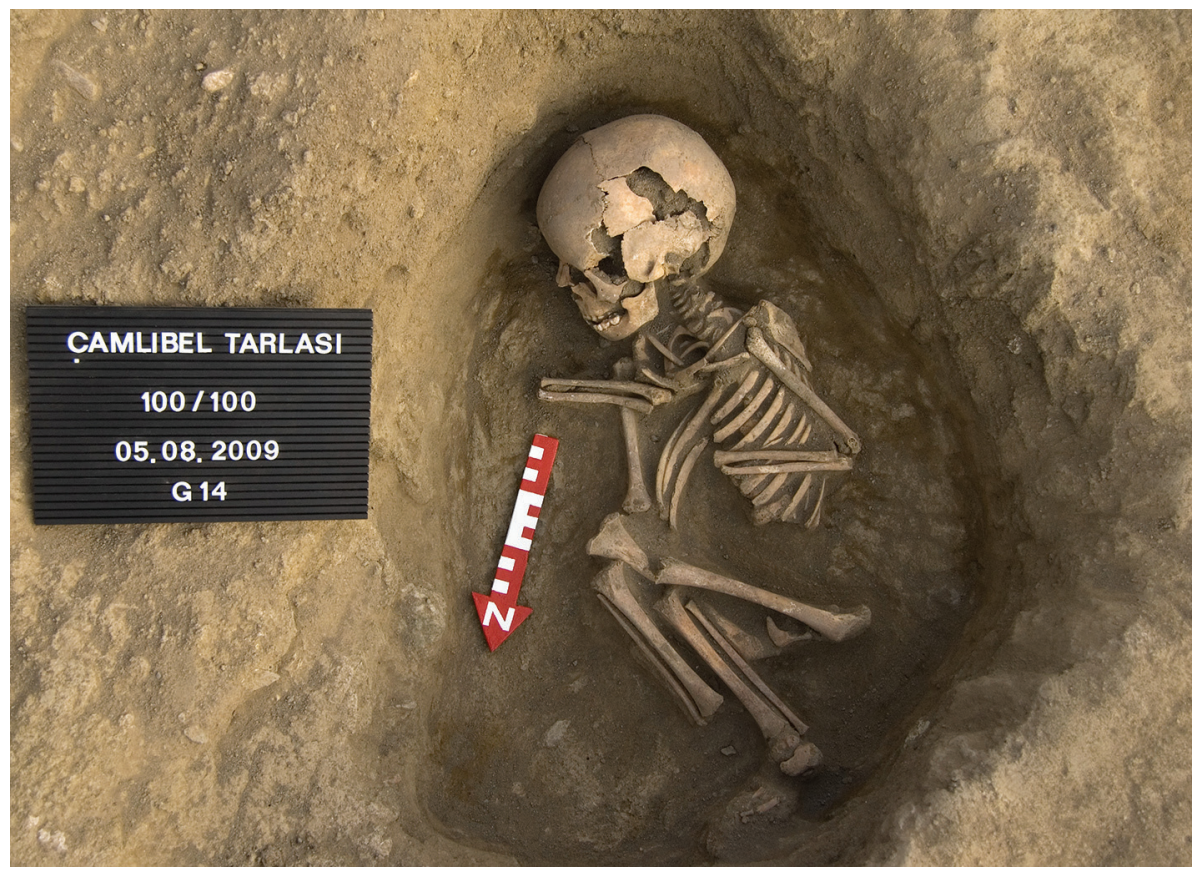


economic and subsistence systems at the site. A large ash deposit from the earliest phase of Çamlıbel Tarlası contained an abundance of cereal grain seeds and flint blades with silica sheen, both of which strongly indicate agricultural activity in the immediate surrounding area (Schoop 2011, 57). However, there are animal remains from Çamlıbel Tarlas1, mainly found in food refuse contexts, which show that there was a substantial reliance on animal husbandry and that wild animals played a minuscule role at the site, contributing only $0.9 \%$ of the overall fragment numbers (Bartosiewicz, Gillis 2011, 77). There was a dominance of beef in the meat diet with cattle bones contributing $2 / 3$ of the faunal assemblage by weight followed by pig and then goat/ sheep (Bartosiewicz, Gillis 2011, 78). The age distribution of the faunal remains shows older cattle and younger pigs, with caprines' ages in between the two extremes (Bartosiewicz, Gillis 2011, 78).

The presence of pig is indicative of a forested and, at least seasonally, humid environment (Bartosiewicz, Gillis, 2011, 78). The area around the Budaközü Plain has undergone significant environmental and geomorphological changes since the Chalcolithic Period. Whilst in the present day the area is semi-arid shrub land, the Chalcolithic environment of the area was partially forested and seasonally humid (Papadopoulou, Bogaard 2013, 132). Erosion has also badly damaged the valley; in pre-historic times the settlement would have been surrounded by small plateaus suitable for small scale agriculture (Marsh 2010, 204). The animal remains profile points towards a "forest village" - a "small agricultural community subsisting in forest clearings, gradually expanding its fields and animal pasturage" (Bartosiewicz, Gillis 2011, 79).

The archaeobotanical research from Çamlıbel Tarlası discovered cereals and pulses; glume wheat, hulled barley, free threshing wheat, lentil, bitter vetch, chickpea, grass pea, Spanish vetchling, and linseed (Papadopoulou, Bogaard 2013, 125-128). The predominant crop was glume wheat (emmer and einkorn), with barley also having a significant presence, and it seemed as though both constituted important components of daily life at Çamlıbel Tarlası (Papadopoulou, Bogaard 2013, 128, 130). The role of wild plants and fruit and nuts does not seem to have played a significant role at Çamlıbel Tarlası (Papadopoulou, Bogaard 2013, 130); the wild assemblage mostly reflects arable habitats, the identified taxa would generally indicate well tilled and fertile conditions (Papadopoulou, Bogaard 2013, 131).

In the fourth and final phase of Çamlibel Tarlası there is a large courtyard between two of the buildings (Schoop 2010b, 36). This courtyard was obviously a place of economic activity, indicated by a large oven and the fact that the floor was strewn with broken lumps of copper slag, two flat anvil stones and numerous pick-marked river pebbles (Schoop 2010b, 36; Schoop 2011, 60). The Late Chalcolithic period in Anatolia sees the emergence of courtyards such as this with ovens, bins and partitions; as also seen at Can Hasan (Sagona, Zimansky 2009, 128). Copper slag was found everywhere in Çamlıbel Tarlası IV, even trampled into the interior floors of houses (Schoop 2011, 59). As well as the bowl furnaces, a casting mould for a ring-shaped figurine and the presence of copper slag, there was additional evidence for metallurgy at Çamlibel Tarlası; fragments of crucibles were found associated with Çamlıbel Tarlası III and Çamlıbel Tarlası IV (Schoop 2011, $60)$. Whilst the abundance of metallurgical evidence makes it clear that metallurgy lies at the heart of human presence at Çamlıbel Tarlası, only a small amount of actual metal objects (mostly copper perforators, needles, wire and one small triangular dagger) were discovered (Schoop 2010a, 198; 2011, 62).

The emergence of copper smelting and working is first seen to be adopted in the Chalcolithic period, from about 5000 BC (Gale 1991, 39, 41; Schoop 2010b, 30; Smith et al. 2003, 122). There is a copper ore deposit only $2 \mathrm{~km}$ upstream from Çamlıbel Tarlası (Marsh 2010, 206), and a Late Chalcolithic presence has been noted there by pottery finds (Schoop 2010b, 36; 2011 57). It therefore seems plausible that this ore outcrop and the presence of small plateaus suitable for agriculture were features that enticed and convinced people to settle there.

\section{Materials and Methods}

Between 2007 and 2009, the remains of 19 individuals were recovered from pot burials and inhumation contexts and another nine individuals were recovered from secondary contexts. The estimations of age, sex, stature and the recording of pathologies of the skeletal material were carried out by Thomas (2011) based on the standards in Buikstra and Ubelaker (1994), Bass (1995) and Byers (2002). These age estimations were compared with the estimations made on examination of just the dental material (Irvine 2011) using the standards and eruption charts in Hillson (1996) and Van Beek (1983). The dental and skeletal age estimations correlated extremely closely. For the dentition, each specific tooth, its location (mandibular or maxillary and left or right), wear score, presence or absence of caries, calculus and abscesses and age was recorded. Identification, placement and siding of the teeth were done using Van Beek (1983) and Baker et al. (2005). Anterior wear was scored using Smith's (1984) standards and molar wear was scored using Brothwell's (1981) standards. Macrowear is generally scored with a rank, from no enamel loss to complete removal of the crown (Schmidt 2010, 68). Most methods for scoring wear are subjective and are often related to the amount of exposed dentine on the occlusal surface, which allows for large amounts of data to be obtained quickly (Mayhall, Kageyama 1997, 463). Ideally, the deciduous and permanent teeth should have been separated to analyse the lesions, wear and pathologies; due, however, to the relatively small sample, the dentition was grouped together for analysis.

Wear and pathologies were examined macroscopically under a bright light with some of the teeth viewed using a Veho VMS-004 USB microscope (with 20x400x magnification). 


\section{Results}

\subsection{Sample representation}

The total dental sample population was comprised primarily of subadults with 26 individuals (from both graves and secondary context isolates) and 282 teeth in total. Seventyseven percent of the teeth studied came from individuals aged from $0-12$ years. Nineteen percent of the sample was made up of adult teeth, with $4 \%$ being from an indeterminate age. Although there was a noticeable bias of deciduous teeth present within the sample, pathological information was still obtained, indicating heavy dental defects and pathologies despite the young age of the children.

From the analysis of the dentition, a number of forms of dental pathologies and attrition were found on numerous teeth from several individuals; these are summarised in Tables 3

Table 1. Wear on the deciduous dentition, $\mathrm{N}$ stands for number of teeth affected.

\begin{tabular}{|c|c|c|c|c|c|c|c|c|c|c|c|c|c|}
\hline \multirow{2}{*}{\multicolumn{2}{|c|}{ Tooth Name }} & \multicolumn{12}{|c|}{ Dental Wear Score, Brothwell (1981) } \\
\hline & & 1 & 2 & $2+$ & 3 & $3+$ & 4 & $4+$ & 5 & $5+$ & $5++$ & 6 & 7 \\
\hline MA & $(\mathbf{N})$ & 4 & 5 & & 1 & & 1 & & 2 & & & & \\
\hline МB & $(\mathbf{N})$ & 7 & 3 & & 4 & & 1 & & & & & & \\
\hline MC & $(\mathbf{N})$ & 11 & 1 & & 2 & & 1 & & 1 & & & 1 & \\
\hline MD & $(\mathbf{N})$ & 7 & 1 & 4 & 1 & 1 & & & 1 & & & & \\
\hline ME & $(\mathbf{N})$ & 9 & 3 & 1 & & & 2 & 1 & & & & & \\
\hline $\mathbf{X A}$ & $(\mathbf{N})$ & 7 & 1 & & 1 & & 1 & & 1 & & & & \\
\hline $\mathbf{X B}$ & $(\mathbf{N})$ & 9 & 2 & & & & & & 1 & & & & \\
\hline $\mathbf{X C}$ & $(\mathbf{N})$ & 6 & 3 & & & & 2 & & 1 & & & & \\
\hline XD & (N) & 8 & 3 & 1 & 2 & 1 & & & & 1 & 1 & & \\
\hline $\mathbf{X E}$ & (N) & 12 & 2 & & & & 1 & & & 1 & 1 & & \\
\hline
\end{tabular}

Table 2. Wear on the permanent dentition, $\mathrm{N}$ stands for number of teeth affected.

\begin{tabular}{|c|c|c|c|c|c|c|c|c|c|c|c|c|c|}
\hline \multirow{2}{*}{\multicolumn{2}{|c|}{ Tooth Name }} & \multicolumn{12}{|c|}{ Dental Wear Score, Brothwell (1981) } \\
\hline & & 1 & 2 & $2+$ & 3 & $3+$ & 4 & $4+$ & 5 & $5+$ & $5++$ & 6 & 7 \\
\hline M1 & $(\mathbf{N})$ & 7 & 3 & & & & & & 3 & & & & \\
\hline M2 & $(\mathbf{N})$ & 4 & 1 & & 2 & & 1 & & & & & & \\
\hline M3 & $(\mathbf{N})$ & 6 & 3 & & & & 1 & & & & & & \\
\hline M4 & $(\mathbf{N})$ & & 3 & & 1 & & & & & & & & \\
\hline M5 & $(\mathbf{N})$ & & & & 3 & & 1 & & & & & & \\
\hline M6 & $(\mathbf{N})$ & 13 & & 2 & 1 & 1 & 1 & & & & 1 & & \\
\hline M7 & $(\mathbf{N})$ & 4 & 1 & 2 & & & 1 & & & 1 & & & \\
\hline M8 & $(\mathbf{N})$ & 2 & & & & & & & & & & & \\
\hline $\mathbf{X} 1$ & $(\mathbf{N})$ & 11 & 1 & & & & 1 & & 1 & & & & \\
\hline $\mathrm{X} 2$ & $(\mathbf{N})$ & 5 & & & & & & & 2 & & & & \\
\hline X3 & $(\mathbf{N})$ & 6 & & & & & 1 & & 1 & & & & \\
\hline X4 & $(\mathbf{N})$ & 2 & 2 & & & & 2 & & & & & & \\
\hline X5 & $(\mathbf{N})$ & 2 & 1 & & & & 1 & & & & & 1 & \\
\hline X6 & $(\mathbf{N})$ & 13 & 1 & 1 & & 1 & 1 & & & 1 & & & \\
\hline X7 & $(\mathbf{N})$ & 2 & 2 & 1 & 1 & & & & & & & & \\
\hline X8 & $(\mathbf{N})$ & & & & & & & & & & & & \\
\hline
\end{tabular}

Table 3. Lesions and pathologies of the dentition.

\begin{tabular}{|c|c|c|c|}
\hline \multirow{2}{*}{ Lesion/Pathology } & \multicolumn{3}{|c|}{ Number of teeth affected } \\
\hline & Deciduous dentition & Permanent dentition & Total \\
\hline Grooving & 0 & 3 & 3 \\
\hline Chipping & 9 & 14 & 23 \\
\hline Caries & 11 & 3 & 14 \\
\hline Enamel Hypoplasia & 0 & 8 & 8 \\
\hline Severe attrition/abrasion (score of $\geq 3$ ) & 35 & 32 & 67 \\
\hline Calculus & 0 & 6 & 6 \\
\hline LHPC (Localised Hypoplasia of the Primary Canine) & 5 & 0 & 5 \\
\hline LSAMAT & 0 & 1 & 1 \\
\hline
\end{tabular}


Table 4. General description of affected teeth from each burial context.

\begin{tabular}{|c|c|c|c|}
\hline Grave number & Number of teeth present & Age & $\begin{array}{r}\text { Description } \\
\end{array}$ \\
\hline 3 & 11 & 18 months & Slight attrition on mandibular $i_{1}$ \\
\hline 4 & 26 & $8-10$ years & $\begin{array}{l}\text { Slight wear on the left and right MC; left and right M6, left X6, right } \\
\text { X6, uneven on right deciduous XC. Extreme uneven wear on right MD } \\
\text { and ME, left XD and XE, right XD and XE. Slight to moderate wear on } \\
\text { the left MD and ME }\end{array}$ \\
\hline 5 & 15 & $6-8$ years & $\begin{array}{l}\text { Slight wear on MC. Moderate to severe wear on right MD and ME, } \\
\text { right M6, right XD and XE }\end{array}$ \\
\hline 6 & 15 & 18 months & Dark brown/purple staining on lingual surface of left XA \\
\hline 7 & 22 & $2-3$ years & $\begin{array}{l}\text { Mandibular M6 shows evidence of a linear enamel hypoplasia; slight } \\
\text { attrition on MB and left XA. LHPC on right MC and left XC }\end{array}$ \\
\hline 8 & 26 & (early 20s) & $\begin{array}{l}\text { Right X1, M2, and left X4 exhibit slight attrition. Moderate uneven } \\
\text { wear on X6; slight wear on X5, X7; uneven wear on X1. Slight wear } \\
\text { on mandibular left and right M5, right M4, right M7, M3 and M2. } \\
\text { Moderate wear on left and right M6. Uneven wear on right M1 }\end{array}$ \\
\hline 12 & 25 & $25-30$ years & $\begin{array}{l}\text { Dentine visible on left X3, X4, and X7. Extreme uneven wear on left } \\
\text { X5 and X6. Moderate wear on right XA and X7. Slight wear on right } \\
\text { X3 and X5. Extreme uneven wear on right M6. Slight to moderate } \\
\text { wear on right M2, M5 and M7. Moderate wear on right M6. Slight to } \\
\text { moderate wear on left M2, M3, M4, and M7. Moderate wear on left } \\
\text { M5. Extreme uneven wear on left M6. Grooving on cemento-enamel } \\
\text { junction of left X5 due to dental probing. Left X2 has labial chipping } \\
\text { and early stages/signs of occlusal groove }\end{array}$ \\
\hline 13 & 2 & 5 years & Moderate, uneven wear on MB \\
\hline 14 & 28 & $4-5$ years & $\begin{array}{l}\text { Extreme wear on MA and MB, dentine revealed. Uneven wear on left } \\
\text { MD and slight wear on right MD. Slight to moderate wear on XB, XC, } \\
\text { and M6. LHPC present on right MC }\end{array}$ \\
\hline Isolate 6319 & 4 & $>12$ years & X6 shows signs of moderate/severe wear \\
\hline Isolate 6337 & 1 & $>12$ years & M7 with extreme uneven wear down past cemento-enamel junction \\
\hline Isolate 4631 & 1 & $>12$ years & XA with occlusal groove \\
\hline
\end{tabular}

and 4. These include caries, calculus, enamel hypoplasias, lesions, and varying degrees of attrition and abrasion. The details for each individual are listed in Table 4. All numerical data that follows are taken from Irvine (2011).

\section{Discussion}

\subsection{Dental attrition and abrasion}

As shown above, numerous teeth from several individuals, specifically juveniles, exhibit varying degrees of dental wear. Dental macrowear is the loss of dental hard tissues as viewed at a macroscopic level (Schmidt 2010, 68). It is a continuous, undirectional, long term and age progressive process resulting from tooth-on-tooth contact and contact between the dentition and food or abrasive material (Bernal et al. 2007, 1048; Erdal 2008, 152; Hillson 1996, 231; Kieser et al. 2001, 206; Lieverse et al. 2007, 333; Scott, Winn 2010, 723; Lev-Tov, Smith 2006, 471; Molnar 2008, 428; Watson 2008, 92; Watson et al. 2011). The severity of dental attrition reflects masticatory load and is influenced by dietary composition and food processing techniques (Lieverse et al. 2007, 333; Schmidt 2010, 71). The main factors that contribute to dental wear are tooth form and structure, occlusal relationships, age, sex, enamel quality, diet, the ingestion of grit, cultural activities and the use of teeth as tools (Deter 2009, 247; Eshed et al. 2006, 153; LevTov, Smith 2006, 471; Watson 2008, 92; Watson et al. 2011).

Dental wear usually results in smooth, flat teeth (Scott, Winn 2010, 723). However, if the wear continues and extends into the dentine, this results in "cupping" as dentine wears more quickly than enamel (Albashaireh, Al-Shorman 2010, 211; Kieser et al. 2001, 210; Scott, Winn 2010, 723). It is interesting to note that the majority $(18 \%$ of total teeth $(\mathrm{N})$ and $58 \%$ of all teeth with a wear score $\geq 3$ ) of the affected teeth are not only from juvenile individuals, but also from deciduous teeth, indicating wear at very young ages. In a study by Deter $(2009,250)$, young agriculturalists, (adolescents from a population involved in subsistence based on agriculture), were found to exhibit wear on their incisors and first molars. Whilst the young agriculturalists in that study were adolescents with permanent dentition, it can be observed that the juveniles and young children from Çamlıbel Tarlası exhibit a very similar (if not as severe) pattern of wear. A number of studies have also shown that agriculturalists are more likely to have dental pathology in childhood than hunter-gatherer populations (Lubell et al. 1994, 212); which again is substantiated by the evidence from Çamlıbel Tarlası.

In previous studies of populations dating to the Chalcolithic (6000-3500 BC) from the Levant and Anatolia, 
it was observed that the dentition displayed substantial and severe dental wear as a result of an abrasive diet or using the teeth as a tool (Alpaslan Roodenberg 2011a, 32; LevTov, Smith 2006, 472, 476; Smith et al. 2003, 129). All the teeth from Çamlıbel Tarlası that displayed substantial wear formed a reversed curve of Monson. This is because an increase in attrition typically concentrates wear on the buccal cusps of the mandibular molar crowns, and lingual cusps of the maxillary molar crowns, flattening the occlusal surface (and the curve of Monson), and then reversing it (Hillson 1996, 237-238; Smith 1984, 46). A reverse curve of Monson is commonly noted in groups with a soft diet, such as agriculturalists, due to the resulting increased toothon-tooth contact and thereby attrition. A soft diet can be indicative of a relatively high carbohydrate intake, notably processed grains.

\subsection{Age differentiated wear}

An interesting observation of the wear on the material was that there appeared to be an age threshold concerning the molar wear of the juveniles. Whilst this was observed in several of the juvenile individuals, it was most pronounced on the juvenile aged 8-10 years from Grave 4. The left and right mandibular and maxillary deciduous molars (MD, ME, $\mathrm{XD}$ and $\mathrm{XE}$ ) of this individual displayed very substantial wear whilst much less so on both sets of first permanent molars (M6 and X6). The pattern of wear on the posterior dentition appears to indicate that from the eruption of the deciduous molars (at around 18 months old), they were engaged in a very wear intensive environment/activity, which was reduced or stopped completely before the age of six.

The age threshold of wear (as seen especially in Grave 4's dentition) raises some interesting questions as its aetiology is so far unknown. Some hypotheses are that the young children of the settlement were involved in occupational activity up until the age of 5 or 6 , or that they lived off a diet based mostly on stone ground grain (possibly as part of the weaning process) whose fine mineral inclusions resulted in rapid abrasion of the relatively softer deciduous enamel of their teeth. However, the pattern of their wear in most cases produces a reverse curve of Monson which is a result of attrition and an indicator of a soft diet. The severity of the wear may result from a combination of attrition from a soft diet and abrasion from the mineral inclusions in their food. It may also simply be the result of soft enamel caused by nutritional deficiency or genetics. Ultimately it could be one, or all of the above.

What is most intriguing, however, about the age-related threshold of the wear pattern is that it very conspicuously coincides with the age differentiation in burial habits noticed at the site. The age divide between jar burials for infants and primary inhumations for older children is also roughly around the age of 5/6, and it may be that these are in some way connected in terms of how juveniles were viewed within the society. This age differentiation of burial rituals was also seen in the Late Chalcolithic layers at Hacinebi (south eastern
Anatolia), where individuals ageing from neonate to four years old were buried in jars (Stein et al. 1996, 211); which quite closely corresponds with the age differentiation at Çamlıbel Tarlası. However, no age related wear was analysed or noticed at Hacinebi, or indeed any other contemporary sites, and therefore there is no comparative data.

It is, however, inevitable that the eruption sequence of the dentition will affect the pattern of wear. The rough eruption sequence for the permanent dentition is as follows; first molar, first and second incisors (6-8 years), canines, premolars, second molar (10-12 years), and finally the third molar at 18 years (Deter 2009, 248). This can help to explain why the first molar (in the permanent dentition) is often the most worn and affected by pathology (Lorkiewicz 2011, 543; Molnar 2008, 429).

\subsection{Caries}

Dental caries are the most common form of dental pathology and are age progressive (Keenleyside 2008, 262; Larsen et al. 1991, 182). Caries are pit lesions caused by a focalised demineralisation of the dental hard tissues through the acidic effects of sugar metabolism by bacterial plaque (Hillson 1979; Hillson 1996, 269; Keenleyside 2008, 264; Larsen et al. 1991, 179; Lieverse et al. 2007, 329; Lukacs 1989, 265; Mays 1998, 148). They are usually found in the fissures and pits of the occlusal surface where dental plaque can accumulate protected from functional wear (Hillson 1996, 272-274; Liebe-Harkort et al. 2011, 56). Caries are most likely to affect molars, then pre-molars, and then anterior teeth (Hillson 1996, 280). The prevalence of caries depends on diet, oral hygiene, fluoride levels in the water and the general immune status of the individual (Palubeckaite et al. 2006, 361). The exposure of the root surface, through trauma or severe wear, makes the root more vulnerable to caries (Albashaireh, Al-Shorman 2010, 211). Carious lesions can ultimately contribute to pulpitis, periodontal disease and AMTL (Keenleyside, 2008, 264; Larsen et al. 1991, 179; Mays 1998, 148). The presence of occlusal caries can suggest the consumption of a soft, non-abrasive food that sticks to the teeth long enough to cause decay (Keenleyside 2008, 264; Palubeckaite et al. 2006, 362). Consequently, caries can provide a link to dietary patterns and the health status of a population (Liebe-Harkort 2010, 168; Liebe-Harkort et al. 2011, 56, 61; Lubell et al. 1994, 210).

The most common pathology, as is to be expected of an agricultural population, in the Çamlıbel Tarlası material was carious lesions which affected $27 \%$ of the total population, but only $5 \%$ of the total teeth $(\mathrm{N})$. This is in contrast with other contemporary sites; for example, the percentage of teeth with caries at the Chalcolithic site of Aktopraklik (northwest Anatolia) was 12.23\% (Alpaslan Roodenberg 2011a, 34). The incidence of caries at Çamlıbel Tarlası is lower than average for agriculturalists and only slightly above those of a mixed subsistence. Previous studies formulated a percentage for caries frequency of the total teeth $(\mathrm{N})$; $1.72 \%$ for hunter-gatherers, $4.37 \%$ for mixed subsistence and $8.56 \%$ for agriculturalists (Mays 1998, 153). This low 
percentage of caries at Çamlıbel Tarlası, in comparison with other agricultural groups, is very uncharacteristic (Hillson 1996, 283). The presence of fully processed glume wheat and hulled barley at Çamlıbel Tarlası, which suggests that they were cultivated and prepared for human consumption (Papadopoulou, Bogaard 2013, 130), would indicate that carbohydrates formed an integral part of their diet. We would thereby expect to see a much higher incidence of caries in the dentition. However, the small size and low incidence of caries may be a result of the consumption of milk and dairy products, which studies have shown may offer some protection against caries (Hillson 1996, 279; Ullinger 2010, 29). This potentially points towards the secondary exploitation of cows for milk as a main/supplementary source of protein, which is further supported by the age profile of the cattle remains, and the presence of churns. It is also possible that sheep and goat were also being milked at the site (Bartosiewicz, Gillis 2011, 78). This has been inferred at other sites (Smith et al. 2003, 130); for example, the cattle remains at the Upper Egyptian site of Hierakonpolis (3800-3600 BC) were mostly adult and it has been therefore suggested that they were exploited for their milk which provided the main source of protein for the population (Gamza, Irish 2012, 3). This is further supported at other Chalcolithic sites by the presence of large ceramic vessels believed to be milk churns (Lev-Tov, Smith 2006, 476; Sauter et al. 2003, 16-17; Smith et al. 2003, 130).

It should, however, be remembered that skeletal samples with few or no carious lesions should not be misinterpreted as free from carious disease (Liebe-Harkort et al. 2011, 61). This may prove to be especially true at Çamlıbel Tarlası where we have quite a small sample, of which there are no adolescents and not many adults at all, and factors such as the age-progressive nature of carious lesions and the effects of PMD and abrasion and attrition should be taken into account.

All but one (94\%) of the caries are occlusal in their location. Young children (0-6 years) had the highest number and percentage of individuals with caries, and the most number of caries of the Çamlıbel Tarlası material; this is to be expected as this group comprised the majority of the skeletal and dental population.

\subsection{Occlusal and interproximal grooving}

The isolated incisor (Figure 4) with the occlusal groove is the only exemplary tooth with this type of wear and is likely to be the result of extra-masticatory use of the teeth. The left X2 from Grave 12 with labial chipping also shows the early stages of an occlusal groove. It has been shown that there is often a direct relationship between chipping and grooving on the anterior teeth and their use in extra masticatory activities. It has been suggested that incisal wear from Aktopraklık is indicative of the continual use of the teeth as a tool or third hand (Alpaslan Roodenberg 2011a, 22).

Most occlusal grooves are widely believed to be the result of using the teeth to soften and hold fibres during weaving, basketry, yarn production, net and cord production and the processing of animal sinews and plant fibres (Alpaslan

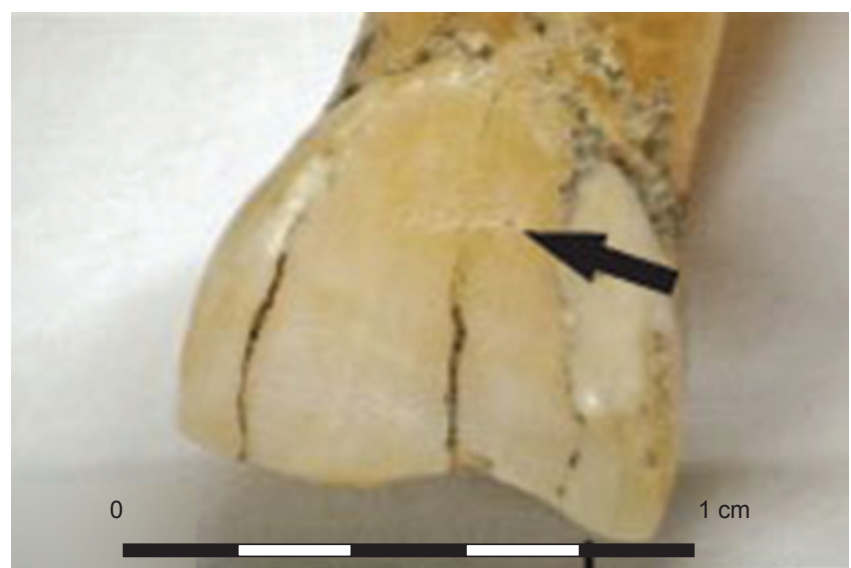

Figure 4. Isolated incisor showing occlusal groove, arrow shows area of LSAMAT (photo by Benjamin Irvine).

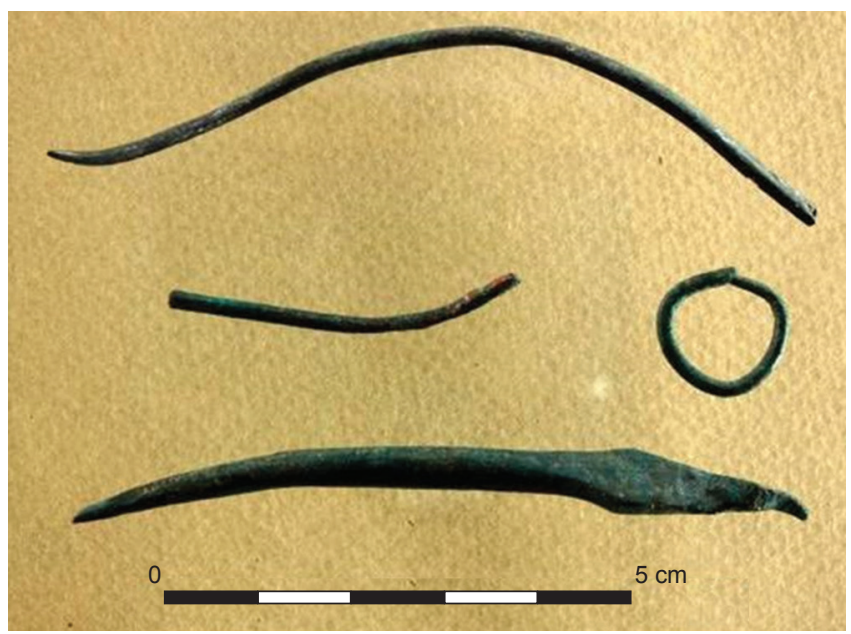

Figure 5. Selection of copper needle, wire, and perforator from Çamlıbel Tarlası (Çamlıbel Tarlası Excavation Archive).

Roodenberg 2011a, 23; Erdal 2008, 159; Lorkiewicz 2011, 539, 545; Milner, Larsen 1991, 366; Molnar 2008, 429; Turner, Anderson 2003; Waters-Rist 2010 et al.). The presence of flax in the floral record (Papadopoulou, Bogaard $2013,128)$ and the potential for the exploitation of wool from sheep (Bartosiewicz, Gillis 2011, 79) along with the presence of copper needles and perforators (Figure 5) would suggest that yarn, fibres and sinews were being processed at Çamlıbel Tarlası and could potentially cause occlusal grooves (Erdal 2008, 161-163).

The occlusal groove could also be the result of habitually holding a cylindrical object between clenched teeth, potentially a copper needle or perforator. The interproximal groove on the left $\mathrm{X} 5$, associated with the individual from Grave 12, may have been formed as the result of habitual use of a toothpick or by the pulling of thread, fibres or sinews between the teeth. Notched teeth are associated with habitually holding a cylindrical object (such as a pin or needle) between the teeth and the action of a sinew or thread 
(Bonfiglioli et al. 2004, 453; Erdal 2008, 158; Lorkiewicz 2011, 547; Turner, Anderson 2003). It has been hypothesised that an individual with notched teeth may be involved in a daily activity/task which required the holding of objects between the teeth to allow full use of both hands; such as a cobbler, carpenter or tailor (Bonfiglioli et al. 2004, 453; Turner, Anderson 2003).

It has been discussed that occlusal grooves often only occur in one of the sexes and generally have a higher prevalence in females of pre-historic populations (Erdal 2008, 164; Lorkiewicz 2011, 541, 545). However, due to the small number of sexed individuals these kinds of inferences, unfortunately, cannot be made at Çamlıbel Tarlası.

\subsection{Chipping}

Dental chipping is an ante-mortem irregular crack in the enamel/enamel and dentine of a tooth (Bonfiglioli et al. 2004, 449), usually on the buccal, lingual, or interproximal edge/crest of the tooth (Milner, Larsen 1991, 370; Molnar 2008, 426). Chipping usually produces irregular, jagged surfaces and often occurs in the presence of tensile stress and a corrosive medium (Kieser et al. 2001, 207; Scott, Winn $2010,723)$. It is generally associated with masticatory and non-masticatory activities and can result from chewing and crushing hard and abrasive foods or extraneous substances (e.g. shell, fruit stones, bone), gripping an object between the teeth or accidental trauma (Bonfiglioli et al. 2004, 452; Molnar 2008, 426; Turner, Eder 2006, 19).

Chipping of the teeth has numerous causes, but is generally the result of a large compression and tensile force whilst biting down on something. One possible explanation for the chipping in the Çamlıbel Tarlası sample is the result of biting down on a hard substance during production activities.

A higher incidence of chipping on the posterior dentition, rather than the anterior, suggests an aetiology related to the diet, mastication techniques, hardness of foodstuffs and the inclusion of foreign particles in the oral cavity, whereas chipping of the anterior dentition often suggests an aetiology of trauma (e.g. a fall or fight) or use of the teeth as a $3^{\text {rd }}$ hand (Turner, Eder 2006, 19). Chipping was observed in six individuals with the majority of the affected teeth being posterior (posterior to anterior ratio of 15:8) and on the left side (left to right ratio of 15:8). The youngest individual with chipping was from Grave 16 (1-2 years) and the oldest was Grave 12 (25-30 years). All of the chipping was noted around the occlusal rim. This predominance of chipping on the posterior dentition and around the occlusal rim would suggest an aetiology related to diet for the population of Çamlıbel Tarlası, notably as a result of the inclusion of mineral particles in the diet.

Chipping has also been noted in archaeological samples in association with non-masticatory use of the dentition. A high rate of excessive and/or oblique wear of the anterior dentition is also associated with the daily use of the teeth as a tool (Albashaireh, Al-Shorman 2010, 211; Deter 2009, 247; Erdal 2008, 158; Krueger, Ungar 2010, 550; Lorkiewicz 2011, 546; Milner, Larsen 1991, 366; Ungar, Spencer 1999,
388). Severe wear of the anterior teeth, but with an absence of chipping suggests the processing of a soft material (Lorkiewicz 2011, 547). In hunter-gatherers heavy anterior tooth wear is typical and reflects the "third hand" use of these teeth as tools preparing hides, sinews and plant fibres (Hillson 1996; 252-253; Kaifu 1999, 496; Lieverse et al. 2007, 335; Lorkiewicz 2011, 547; Scott, Winn 2010, 729; Watson et al. 2011). This can be seen, for example, in the high rate of anterior tooth wear amongst the hunter-gatherers of the Green River Valley in North America (Deter 2009, 250).

It is thought that in prehistoric populations chipping may be the result of using the teeth as a "third hand" in lithic production, for example, when re-touching stone tools and it has been argued that the dental marks from occupational use of the teeth reflect the complexity of behaviours and manufacture (Bonfiglioli et al. 2004, 452; Milner, Larsen 1991, 370; Lorkiewicz 2011, 545). At Çamlıbel Tarlası more than $90 \%$ of the lithic assemblage is made from local red chert and was undeniably produced on site (Schoop 2011, 64). Non-masticatory dental wear/marks can be caused by holding or working an object or material ("third hand" use of the teeth), tool preparing, skin softening, and specific modifications as a result of specialised craft activities such as basketry and yarn production (Lorkiewicz 2011, 545; WaterRist et al. 2010). In terms of the metallurgical activities onsite, after acquiring the ore it would need to be broken and crushed into coarse lumps and then sorted and washed by hand. It is not inconceivable that some of the wear observed in the Çamlıbel Tarlası material may be the result of holding material/objects whilst crushing, sorting or washing ore to free up the use of both hands.

Generally, occupational related abrasion only affects several teeth (Gamza, Irish 2012, 8).

\subsection{Cupping}

Many of the teeth displayed "cupping". Numerous studies have noted that agriculturalists often develop cupped out molars in particular (Lubell et al. 1994, 210; Smith 1984, 47). It has been discussed that the presence of fine mineral particles from grain processing/grinding may result in "cupping" (Smith 1984, 47). Many of the dental remains from Göndürle Höyük, Harmanören (2500 BC) in south western Turkey displayed a certain degree of wear that was attributed to the inclusion of small stone and sand particles in the diet from the milling process (Alpaslan Roodenberg 2011b, 3). It is hypothesized that the cupping found at Çamlıbel Tarlası may be due to similar production activity and the subsequent inclusion of mineral particles in the diet as grinding stones were found and the archaeobotanical study discovered that the cereals present had been fully processed. Whilst the presence of grinding stones at Çamlıbel Tarlası may suggest plant processing, they may have other functions as well (Bernal et al. 2007, 1054-1055). This could well be the case at Çamlıbel Tarlası where grinding stones could have been used for processing grains or involved in the metallurgical process, notably the crushing of ore and slag (Schoop 2011, 
$60)$.

Furthermore, from the presence of "bee-hive" shaped ovens at the site in conjunction with the full processing of cereals we can infer that bread was being baked and contributed to the inhabitants' diet. The method for baking bread would have resulted in the inclusion of mineral particles and ash from the oven base and environment. These mineral inclusions from the baking process would have contributed to the cupping, chipping and abrasion of the dentition.

The agricultural lifestyle of Çamlıbel Tarlası is one that is based predominantly outdoors and it should also be considered that agricultural processes such as digging and tending to the fields can result in the inclusion of dust and soil into the oral cavity which can over time cause dental abrasion and contribute to the rate and nature of the cupping of the dentition (Scott, Turner 1988, 110).

\subsection{Enamel hypoplasias, discolouration and LHPC (Localised Hypoplasia of Primary Canine)}

Dental enamel hypoplasia is a disturbance/disruption in the formation of enamel during a tooth's development (Hillson 1979; Lukacs 1989, 267; Keenleyside 2008, 265; Palubeckaite et al. 2006, 356). It is usually observed as a transverse line or band of depressed enamel on the sides of the tooth crown and is believed to possibly indicate dietary/ nutritional deficiencies or physiological stress (such as illness) in childhood (Hillson 1979; Keenleyside 2008, 265; Lieverse et al. 2007, 327; Lukacs 1989, 267; Mays 1998, 156; Smith et al. 2003, 128).

The presence of enamel hypoplasias within the Çamlibel Tarlas1 population indicates nutritional and/or physiological stress during childhood. Estimating the age of stress in correlation with the location of the enamel defect on the tooth is not considered to be a highly accurate technique; it is generally accepted, however, that the stress that could cause enamel hypoplasia can occur between the ages of 0 and 7 years; 13 if on the third molar (Mays 1998, 156).

A number of studies have shown that an adoption of and an increase in reliance on arable agriculture results in an increase in the frequency of enamel hypoplasia. For example, at Dickson Mounds in Illinois enamel hypoplasia was found in $45 \%$ of hunter-gatherers, $60 \%$ of the transitional group and $80 \%$ of intense agriculturalists (Lukacs 1989, 281). Only two individuals, $8 \%$ of the skeletal population, and 8 teeth (all permanent) exhibited enamel hypoplasia. This low frequency, relative to other agricultural populations, at Çamlıbel Tarlası may be due to the predominant analysis of deciduous dentition within the sample. While the population at Çamlıbel Tarlası may have been reliant on a form of agriculture, the sample size is too small to make definite comparisons with percentages found at other sites.

Dark brown, almost bluish/purple, staining was discovered on the lingual surface of a maxillary incisor from an 18 month old (Grave 6) and reddish brown staining was found on the right sided teeth (mainly the anterior maxillary dentition) from a 4-5 year old (Grave 14). The exact aetiology of this staining could not be concluded but several hypotheses may

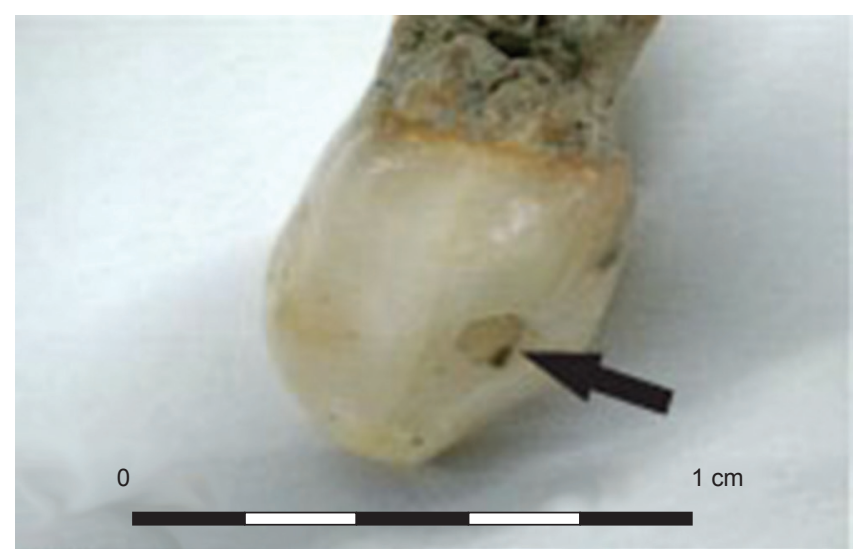

Figure 6. LHPC (indicated with arrow) on the labial surface of a permanent canine (photo by Benjamin Irvine.)

be put forward. The staining could be the result of trauma and subsequent bleeding, fluorosis, disease such as porphyria related erythrodontia or a taphonomic effect such as the soil or minerals in it. This discoloration of the teeth merits further research in the near future.

Observations were made of a roughly circular depression/ loss of enamel on the labial surface of some of the deciduous anterior teeth, and canines in particular (Figure 6).

These circular enamel depressions are most likely to be LHPC. This is an enamel defect that is found on deciduous teeth and is thought to be related to malnutrition and in particular a low dietary fat and calcium intake by the mother during pregnancy and a lack of vitamins A and D (Mcdonell, Oxenham 2012; Skinner, Newell 2000). It is, however, more often related to pre/peri natal trauma; falls, blows to the mouth or during birth (Mcdonell, Oxenham 2012; Taji et al. 2000, 83-84). The two may not be unrelated, however, as soft enamel due to vitamin D deficiency will more likely be damaged by a traumatic event. The hypothesis about a high milk intake by the inhabitants of Çamlıbel Tarlası, if correct, would also suggest that the LHPC observed is as a result of trauma. LHPC may also be related to thin enamel in the area of the depression and therefore may be related to genetics, and be a hereditary trait (Taji et al. 2000, 83, 88).

On the upper labial surface of the isolated incisor, a small circular depression is also visible. This is not likely to be LHPC, but rather LSAMAT (lingual surface attrition of the maxillary anterior teeth), which is related to the use of the maxillary incisor (Scott, Turner 1988, 112) and specifically the pressing of leather or sinew against the tooth whilst sucking them as part of the preparation technique.

\section{Conclusion}

With a low prevalence of calculus (one individual and 2\% of the total tooth $\mathrm{N}$ ), attrition producing oblique wear and a reverse curve of Monson, and "cupping" of the dentition the dental material would suggest that the people of Çamlibel Tarlası were relatively typical of a population with a diet 
and subsistence based on mixed agriculture and grains/ carbohydrates. There are, however, some characteristics which distinguish them in the Chalcolithic Period in the Near East, and especially Anatolia. The low incidence of caries, less than half of that of other contemporary agricultural populations, would suggest that either there was a higher reliance on meat in the diet than the floral and faunal data point to, or that the population was consuming copious amounts of milk. Without further data, notably isotopic analysis of the human remains; which is currently on-going, it is difficult to say whether these hypotheses are correct with any real certainty. The age differentiated wear seen on the juveniles is extremely interesting and merits further research, such as analysis with SEM to better determine the aetiology of the wear. The application of SEM to study the microwear of the dentition is something that should also be applied to the complete dental sample. The question of age differentiated wear should also be addressed and looked out for in other temporally and geographically contemporary populations to determine whether there are any patterns or evidence for determining the reasons (both physically and culturally) for this distinctive wear pattern.

Further analysis and research also needs to be made to determine better the aetiology of the discoloured teeth noticed on some of the dentition of the population.

In terms of extra-masticatory use, there are several clues such as an interproximal groove, occlusal grooves on incisors, LSAMAT and severe wear patterns (particularly in sub-adults) which indicate that the population at Camlibel Tarlasi were occupationally using their teeth as either a tool or a third hand. The working of fibres, yarn and sinews can be inferred in conjunction with the evidence from the dentition by the presence of flax in the floral assemblage and the probability that wool was being exploited from sheep, along with the finds of copper needles and perforators. The use of teeth in lithic production as well as during the metallurgical process cannot be ruled out, as both of these industries seem to be fundamental to existence at Çamlıbel Tarlası.

\section{Acknowledgements}

We would like to thank Dr Ulf Schoop, head of the Çamlıbel Tarlas1 excavations, for allowing us access to the skeletal and archaeological material, as well as the photographs and drawings from the project archive, and for all his help and advice. Thank you as well to Florence Irvine for editing some of the photographs. The advice and comments of Dr Y1lmaz Selim Erdal of Hacettepe University, Ankara are also greatly appreciated.

\section{References}

ALBASHAIREH, Z. S. M., AL-SHORMAN, A. A. 2010: The frequency and distribution of dental caries and tooth wear in a Byzantine population of Sa'ad, Jordan. International Journal of Osteoarchaeology 20, 205 213.
ALPASLAN ROODENBERG, M. S. 2011a: A preliminary study of the burials from Late Neolithic - Early Chalcolithic Aktopraklik. Anatolica 37, 17-43.

ALPASLAN ROODENBERG, M. S. 2011b: Harmanören - Göndürle Höyük Mezarlığı İskeletlerinin Antropolojik Analizi. In: Şahin, H., Konyar, E., Ergin, G. (Eds): Studies Presented to Mehmet and Nesrin

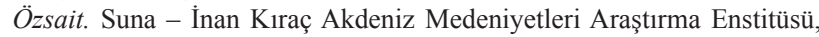
Antalya 2011, 1-9.

BAKER, B. J., DUPRAS, T. L., TOCHERI, M. W. 2005: The osteology of infants and children. Texas A\&M University Press, College Station.

BARTOSIEWICZ, L., GILLIS, R. 2011: Preliminary report on the animal remains from Çamlıbel Tarlası, Central Anatolia. Archäologischer Anzeiger 2011, 76-79.

Van BEEK, G. C. 1983: Dental Morphology: An illustrated guide. Wright, Edinburgh.

BERNAL, V., NOVELlinO, P., GONZALES, P. N., PEREZ, S. I. 2007: Role of wild plant foods among Late Holocene hunter-gatherers from Central and North Patagonia (South America): An approach from dental evidence. American Journal of Physical Anthropology 133, 1047-1059.

BONFIGLIOLI, B., MARIOTTI, V., FACCHINI, F., BELCASTRO, M. G., CONDEMI, S. 2004: Masticatory and non-masticatory dental modifications in the Epipalaeolithic necropolis of Taforalt (Morocco). International Journal of Osteoarchaeology 14, 448-456.

BROTHWELL D. 1981: Digging up bones. Cornell University Press, Ithaca.

DETER, C. A. 2009: Gradient of occlusal wear in hunter-gatherers and agriculturalists. American Journal of Physical Anthropology 138, 247 254.

ERDAL, Y. S. 2008: Occlusal grooves in anterior dentition among Kovuklukaya inhabitants (Sinop, Northern Anatolia, $10^{\text {th }}$ Century AD). International Journal of Osteoarchaeology 18, 152-166.

ESHED, V., GOPHER, A., HERSHKOVITZ, I. 2006: Tooth wear and dental pathology at the advent of agriculture: New evidence from the Levant. American Journal of Physical Anthropology 130, 145-159.

GALE, N. H. 1991: Metals and metallurgy in the Chalcolithic Period. Bulletin of the American Schools of Oriental Research 282/283, 37-61.

GAMZA, T., IRISH, J. 2012: A comparison of archaeological and dental evidence to determine diet at a Pre-Dynastic Egyptian site. International Journal of Osteoarchaeology 22, 398-408.

HILLSON, S. W. 1979: Diet and dental disease. World Archaeology 11.2, $147-162$.

HILLSON, S. 1996: Dental Anthropology. Cambridge University Press, Cambridge.

HILLSON, S. 2000: Dental pathology. In: Katzenberg, M. A., Saunders, S. R. (Eds.): Biological anthropology of the human skeleton. Wiley-Liss, New York.

IRVINE, B. 2011: A study of the dentition from the Late Chalcolithic site of Camlıbel Tarlası, north central Anatolia. MS. Master Thesis in Human Osteoarchaeology. Deposited: University of Edinburgh, Edinburgh, UK.

KAIFU, Y. 1999: Changes in the pattern of tooth wear from Prehistoric to recent periods in Japan. American Journal of Physical Anthropology 109, 485-499.

KEENLEYSIDE, A. 2008: Dental pathology and diet at Appolonia, a Greek colony on the Black Sea. International Journal of Osteoarchaeology 18, 262-279.

KIESER, J. A., DENNISON, K. J., KAIDONIS, J. A., HUANG, D., HERBISSON, P. G. P., TAYLES, N. G. 2001: Patterns of dental wear in the early Maori dentition. International Journal of Osteoarchaeology 11, 206-217.

KRUEGER, K. L., UNGAR, P. S. 2010: Incisor microwear textures of five bioarchaeological groups. International Journal of Osteoarchaeology 20, 549-560.

LARSEN, C. S., SHAVIT, R., GRIFFIN, M. C. 1991: Dental caries evidence for dietary change: An archaeological context. In: Kelley, M. A., Larsen, C. S. (Eds): Advances in Dental Anthropology. Wiley-Liss, New York, 179-202.

LEV-TOV, N., SMITH, P. 2006: Variation in occlusal dental wear of two Chalcolithic populations in the Southern Levant. American Journal of Physical Anthropology 130, 471-479.

LIEBE-HARKORT, C. 2010: Exceptional rates of dental caries in a Scandinavian Early Iron Age population: A study of dental 
pathology at Alvastra, Östergötland, Sweden. International Journal of Osteoarchaeology 22, 168-184.

LIEBE-HARKOR, C., ASTVALDSDOTTIR, A., TRANAEUS, S. 2011: Visual and radiographic assessment of dental caries by osteologists: A validity and reliability study. International Journal of Osteoarchaeology 21, 55-65.

LIEVERSE, A. R., LINK, D. W., BAZALIISKIY, V. I., GORIUNOVA, O. I., WEBER, A. W. 2007: Dental health indicators of hunter-gatherer adaptation and cultural change in Siberia's Cis-Baikal. American Journal of Physical Anthropology 134, 323-339.

LORKIEWICZ, W. 2011: Non-alimentary tooth use in the Neolithic population of the Lengyel Culture in central Poland (4600-4000 BC). American Journal of Physical Anthropology 144, 538-551.

LUBELL, D., JACKES, M., SCHWARCZ, H., KNYF, M., MEIKLEJOHN, C. 1994: The Mesolithic-Neolithic transition in Portugal: Isotopic and dental evidence of diet. Journal of Archaeological Science 21, 201-216.

LUKACS, J. R. 1989: Dental paleopathology: Methods for reconstructing dietary patterns. In: İşcan, M. Y., Kennedy, K. A. R. (Eds.): Reconstruction of life from the skeleton. Alan R. Liss, New York, 261-286.

MARSH, B. 2010: Geoarchaeology of the human landscape at BoğazköyHattuşa. Archäologischer Anzeiger 2010, 201-207.

MAYHALL, J. T., KAGEYAMA, I. 1997: A new three dimensional method for determining tooth wear. American Journal of Physical Anthropology 103, 463-469.

MAYS, S. 1998: The archaeology of human bones. Routledge. London.

MCDONELL, A., OXENHAM, M. F. 2012: Localised primary canine hypoplasia: Implications for maternal and infant health at Man Bac, Vietnam, 4000-3500 years BP. International Journal of Osteoarchaeology. Online First. Doi: 10.1002/oa.2239.

MILNER, G. R., LARSEN, C. S. 1991: Teeth as artefacts of human behaviour: Intentional mutilation and accidental modification. In: Kelley, M. A., Larsen, C. S. (Eds.): Advances in Dental Anthropology. WileyLiss, New York, 357-378.

MOLNAR, P. 2008: Dental wear and oral pathology: Possible evidence and consequences of habitual use of teeth in a Swedish Neolithic sample. American Journal of Physical Anthropology 136, 423-431.

PALUBECKAITE, Z., JANUKAUSKAS, R., ARDAGNA, Y., MACIA, Y., RIGEADE, C., SIGNOLI, M., DUTOUR, O. 2006: Dental status of Napoleon's Great Army's (1812) mass burial of soldiers in Vilnius: Childhood peculiarities and adult dietary habits. International Journal of Osteoarchaeology 16, 355-365.

PAPADOPOULOU, I., BOGAARD, A. 2013: A preliminary study of the charred macrobotanical assemblage from Çamlibel Tarlasi, north-central Anatolia. In: Schachner, A. (Ed.): Die Ausgrabungen in BoğazköyHattuşa 2011. Archäologischer Anzeiger 2012, 123-132.

SAGONA, A., ZIMANSKI, P. 2009: Ancient Turkey. Routledge, New York.

SAUTER, F., PUCHINGER, L., SCHOOP, U. D. 2003: Studies in organic archaeometry VI. Fat analysis sheds light on everyday life in prehistoric Anatolia: Traces of lipids identified in chalcolithic potsherds excavated near Boğazkale, Central Turkey. ARKIVOC XV, 15-21.

SCHMIDT, C. W. 2010: On the relationship of dental microwear to dental macrowear. American Journal of Physical Anthropology 142, 67-73.

SCHOOP, U. D. 2008: Ausgrabungen in Çamlıbel Tarlası 2007. In: Schachner, A. (Ed.): Die Ausgrabungen in Boğazköy-Hattuşa 2007. Archäologischer Anzeiger 2008, 148-157.

SCHOOP, U. D. 2009: Ausgrabungen in Çamlıbel Tarlası 2008. In: Schachner, A. (Ed.): Die Ausgrabungen in Boğazköy-Hattuşa 2008. Archäologischer Anzeiger 2009, 56-66.

SCHOOP, U. D., GRAVE, P., KEALHOFER, L., JACOBSEN, G. 2009: Radiocarbon dates from Chalcolithic Çamlıbel Tarlası. In: Schachner, A. (Ed.): Die Ausgrabungen in Boğazköy-Hattuşa 2008, Archäologischer Anzeiger 2009, 66-67.

SCHOOP, U. D. 2010a: Ausgrabungen in Çamlıbel Tarlası 2009. In: Schachner, A. (Ed.): Die Ausgrabungen in Boğazköy-Hattuşa 2009. Archäologischer Anzeiger 2010, 191-201.
SCHOOP, U. D. 2010b: Some thoughts on social and economic development in Western Anatolia during the fourth and third millennia BC. In: Bilgen, A. N., von Den Hoff, R., Sandalcı, S., Silek, S. (Eds.): Archaeological research in Western Central Anatolia. Proceedings of the IIIrd International Symposium of Archaeology, Kütahya. 8th-9th March 2010. Dumlupınar University Department of Archaeology, Kütahya 2011, 29-45.

SCHOOP, U. D. 2011: Çamlıbel Tarlası, ein metallverarbeitender Fundplatz des vierten Jahrtausends v. Chr. im nördlichen Zentralanatolien. In: Yalçın, Ü. (Ed.): Anatolian Metal V. Deutsches Bergbau Museum, Bochum, 53-68.

SCOTT, G. R., TURNER, C. G. 1988: Dental Anthropology. Annual Review of Anthropology 17, 99-126.

SCOTT, G. R., WINN, J. R. 2010: Dental chipping: Contrasting patterns of Microtrauma in Inuit and European populations. International Journal of Osteoarchaeology 21, 723-731.

SKINNER, M., NEWELL, E. 2000: A re-evaluation of localized hypoplasia of the primary canine as a marker of craniofacial osteopenia in European Upper Paleolithic infants. ACTA Universitatis Carolinae. Medica (Praha) 41, 41-58.

SMITH, B. H. 1984: Patterns of molar wear in hunter gatherers and agriculturalists. American Journal of Physical Anthropology 63, 39-56.

SMITH, P. E. L., GOPHER, A., LEV-TOV, N. 2003: Dental evidence for dietary practices in the Chalcolithic period: The findings from a burial cave in Peqi' in (Northern Israel). Paleorient 29.1, 121-134.

STEADMAN, S. R., ROSS, J. C., McMAHON, G., GORNY, R. L. 2008: Excavations on the north-central plateau: The Chalcolithic and Early Bronze Age occupation at Çadır Höyük. Anatolian Studies 58, 47-86.

STEIN, G.T., BERNBECK, R., COURSEY, C., McMAHON, A., MILLER, N. F., MISIR, A., NICOLA, J., PITTMAN, H., POLLOCK, S., WRIGHT, H. 1996: Uruk colonies and Anatolian communities: An interim report on the 1992-1993 excavations at Hacinebi, Turkey. American Journal of Archaeology 100.2, 205-260.

TAJI, S., HUGHES, T., ROGERS, J., TOWNSEND, G. 2000: Localised enamel hypoplasia of human deciduous canines: genotype or environment? Australian Dental Journal 45, 83-90.

THOMAS, J. 2011: Preliminary Observations on the Human Skeletal Remains from Çamlıbel Tarlası. Archäologischer Anzeiger 2011, 73-76.

TURNER, G. ANDERSON, T. 2003: Marked occupational dental abrasion from Medieval Kent. International Journal of Osteoarchaeology 13, $168-172$.

TURNER, G, EDER, J. F. 2006: Dental pathology, wear, and diet in a hunting and gathering forest-dwelling group: The Batak people of Pawan Island, The Philippines. Dental Anthropology 19.1, 15-22.

ULLINGER, J. M. 2010: Skeletal health changes and increasing sedentism at Early Bronze Age Bab edh-Dhra, Jordan. MS. Doctoral dissertation. Deposited: The Ohio State University. http://etd.ohiolink.edu/view. cgi?acc_num $=$ osu1275258919: 1-204.

UNGAR, P. S., SPENCER, M. A. 1999: Incisor microwear, diet and tooth use in three Amerindian populations. American Journal of Physical Anthropology 109, 387-396.

WATERS-RIST, A., BAZALIISKII, V. I., WEBER, A., GORIUNOVA, O. I., KATZENBERG, M. A. 2010: Activity induced dental modification in Holocene Siberian hunter-fisher-gatherers. American Journal of Physical Anthropology 143, 266-278.

WATSON, J. T. 2008: Changes in food processing and occlusal dental wear during the early agricultural period in North West Mexico. American Journal of Physical Anthropology 135, 92-99.

WATSON, J. T., ARRIAZA, B., STANDEN, V., MUNOZ OVALLE, I. 2013: Tooth wear related to marine foraging, agro-pastoralism and the formative transition on the Northern Chilean coast. International Journal of Osteoarchaeology 23.3, 287-302. 